\title{
PALATAL MYOCLONUS
}

\section{REPORT OF TWO CASES}

\author{
GIORGIO FABIANI*, HÉLIO A. G. TEIVE**, DANIEL SÁ*, CLÁUDIA K. KAY*, \\ ROSANA H. SCOLA**, MÁRCIO MARTINS ${ }^{* * *}$, LINEU CÉSAR WERNECK ${ }^{* * * *}$
}

\begin{abstract}
We describe two cases of palatal myoclonus (PM), one essential and another secondary to a stroke. Case 1: a 64 years old female who developed clicking sounds in both ears after a stroke and three years later on noticed a progressive involuntary movement of the throat associated with rhythmic contractions of the soft palate, muscles of tongue and throat. MRI showed an ischemic area in brainstem. The patient had a partial response to the use of sumatriptan $6 \mathrm{mg}$ subcutaneously. Case 2: a 66 years old female who began with ear clicking at left ear that worsed slowly associated with tinnitus and arrhythmic movements of soft palate and an audible click at left ear. Brain MRI was normal; audiometry showed bilateral neurosensory loss. She was prescribed clonazepan $1 \mathrm{mg}$ daily with complete recovery. Primary and secondary palatal myoclonus share the same clinical features but probably have different pathophysiological underlying mechanisms.
\end{abstract}

KEY WORDS: palatal myoclonus, sumatriptan, clonazepan.

\section{Mioclonia palatal: relato de dois casos}

RESUMO - Descrevemos dois casos de mioclonia palatal (MP), um essencial e o outro secundário a acidente vascular cerebral (AVC). Caso1: mulher de 64 anos que desenvolveu cliques audíveis em ambos os ouvidos após um AVC e que três anos depois começou a apresentar movimentos involuntários do pálato, músculos do língua e garganta. A ressonância magnética (RNM) mostrou áreas de isquemia no tronco cerebral. A paciente apresentou resposta parcial e não duradoura ao uso subcutâneo de $6 \mathrm{mg}$ de sumatriptano. Caso 2: mulher de 66 anos, com cliques audíveis no ouvido esquerdo que pioraram progressiva e lentamente associados com tinitus e movimentos mais ou menos rítmicos do pálato mole. A RNM encefálica era normal. A audiometria mostrou perda neurossensorial bilateral. Foi medicada com 1,0 mg de clonazepan diariamente com completa recuperação. MP primária e secundária compartilham das mesmas características clínicas, mas evidências sugerem que se devam a diferentes mecanismos fisiopatológicos.

PALAVRAS-CHAVE: mioclonia palatal, sumatriptano, clonazepan.

Palatal myoclonus (PM) is a form of segmental myoclonus. It is an uncommon, rhythmic, "shock-like" involuntary movement of the muscles of soft palate, throat and other structures derived from the branchial $\operatorname{arcs}^{1-3}$. Some authors prefer to call it palatal tremor ${ }^{3}$. Jankovic suggests that the most correct term shall be $\mathrm{PM}^{4}$. Although it is a rare condition, it is well established that the anatomic structures involved in the process are almost always in the inferior olivary nucleus - that show an hypertrophic degeneration ${ }^{1-3,5,6}$.

Division of Neurology, Internal Medicine Department, Universidade Federal do Paraná(HC-UFPR), Curitiba, Brazil: *Neurologista e mestrando em Medicina Interna(HC-UFPR); **Professor assistente de Neurologia do Departamento de Clínica Médica(HC-UFPR); *** Médico Residente de Otorrinolaringologia do Hospital Angelina Caron- Curitiba/PR; ****Professor Titular de Neurologia do Departamento de Clínica Médica (HCUFPR). Aceite: 24-junho-2000.

Dr. Giorgio Fabiani - Rua Paula Gomes 734 / 202 - 80510-070 Curitiba PR - Brasil. FAX 412643606. E-mail: giorgiof@osite.com.br 
Our objective is to report two cases PM, one secondary to a stroke that had a partial response to the administration of sumatriptan and one case of essential PM with excellent response to low doses of clonazepan.

\section{CASES}

Case 1. A 64 years old female have had a stroke 10 years before with sudden disarthria, oral-paresthesias and right hand numbness. The symptoms recovered completely after 14 days. Some months later she noticed clicking sounds in both ears, that worsened when she was silent and in a very quiet place. Three years later she began with progressive involuntary movements of the soft palate with progression to the muscles of the tongue and throat. The movements did not disappear even during sleep. The patient was unable to voluntarily suppress the movement. There was no maneuver of reducing the clicking sounds in both ears. She had a past history of systemic hypertension that was under control and depression under treatment with amitryptiline. Physical examination was completely normal except by visible muscular movements of the soft palate and in the anterior neck muscles at the rate of $120 / \mathrm{min}$. There was an audible click in the mastoids with the stethoscope examination. A brain MRI showed ischemic areas in cerebral peduncles and semi-oval centers(lacunae) (Fig 1). The patient was submitted to surface electromyography of the anterior muscles of the neck (Fig 2). The electromyogram recorded at $2 \mathrm{~s}$ showed bursts of electrical activity at firing rate of 3 per second, prior to the administration of the sumatriptan. After 10 minutes of the subcutaneous (SC) injection of $6 \mathrm{mg}$ of sumatriptan, electromyogram recorded at $2 \mathrm{~s}$ showed irregular bursts of electrical activity at firing rate 2 per 2 second for some minutes and the patient reported a subjective improvement for some hours. Trials with different drugs were performed, (clonazepan 2 $\mathrm{mg} 8 / 8$ hours, valproic acid $500 \mathrm{mg} 8 / 8$ hours; L- DOPA $250 \mathrm{mg}$ daily; piracetan up to $2.4 \mathrm{~g}$ daily; carbamazepine $400 \mathrm{mg}$ daily), and were completely ineffective.

Case 2. A 66 years old female, who began to hear ear clicking on left ear 3 years previously. These clickings worsened slowly and she began to feel involuntary movements of the throat. Simultaneously she noticed
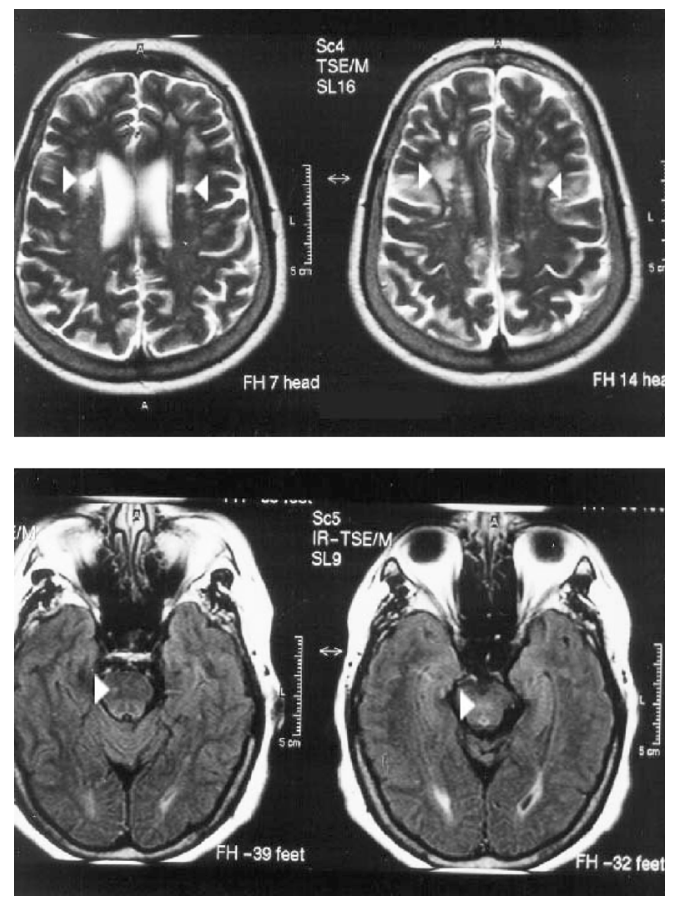

Fig 1. MRI (brain and brainstem, case 1). Brain MRI - flair and T2 - weighted showing (white arrows) ischemic areas in semi-oval center (lacunae), cerebral peduncles/brainstem. 


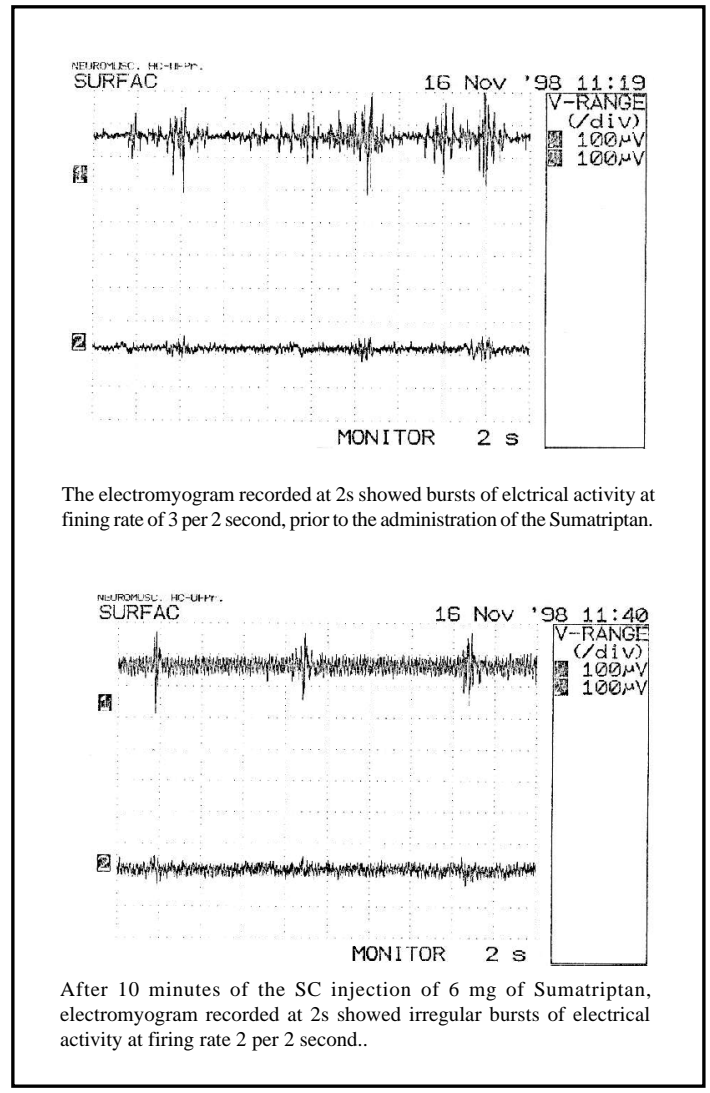

Fig 2. Electromyography (sumatriptan in the Case 1).

a progressive loss of hearing in both ears. The patient had a past history of hypothyroidism in treatment. A brain MRI was completely normal. An audiometry showed bilateral neurosensory loss. On examination the patient had an audible click on left ear (audible even without stethoscope), a decrease of hearing ( of neurosensory pattern) and involuntary movements of soft palate( up-down), arrhythmic at a rate of 60/80 movements per minute. A trial with clonazepan $0.5 \mathrm{mg} \mathrm{12/12}$ hours was effective and both palatal myoclonus and left ear clickings were completely vanished.

\section{DISCUSSION}

The anatomy and pathology of PM is well established and the most common finding is hypertrophic degeneration of the inferior olivary nucleus involving the Guillain Mollaret triangle (dentate nucleus, red nucleus, inferior olivary nucleus and central tegmental tract) ${ }^{1,-3,5,6}$. This seems to be caused by a supra olivary lesion. Most theories propose an involvement of the pathways connecting the cerebellum to the inferior olivary nucleus ${ }^{1-3,5,6}$. Dubinski et al. showed increased glucose metabolism in the medulla of 7 patients with $\mathrm{PM}^{7}$.

There is almost always a delay between the occurrence of presumed anatomical lesions and the recognition of palatal myoclonus. This finding suggest that the inferior olivary nucleus or the surrounding are hypermetabolic and can be the pacemakers of the $\mathrm{PM}^{7}$. It has been shown that hypertrophy of neurons in the contralateral medial/dorsal accessory olive develops in cats after hemicerebellectomy within 8 months ${ }^{8}$. The same happens in rats. The PM movement persists in the sleep state. Most cases of PM are secondary and a review of 278 cases published by Deuschl et al. 
found that 210 out 278 were symptomatic ${ }^{2}$.The most common lesions associated to secondary PM are: stroke, trauma, tumor, demyelinating diseases. There is a case of PM after extirpation of a cerebellar astrocytoma9.

Martinez-Vila et al. in 1993 published a case of PM related with opioid peptides in a patient with 53 years old with carcinoma of larynx. They noticed that there was a worsening of PM after injections of midazolan, morphine and naloxone and improvement with phentanyl. These findings suggest the role of opioids peptides in the genesis of PM. The patient showed a complete improvement of PM after extirpation of the larynx carcinoma even without the need of opioid agonists ${ }^{10}$.

Scott et al. in 1996 reported the treatment of palatal myoclonus in 2 patients, one with primary palatal myoclonus-PPM (showed a positive response) and the other with secondary palatal myoclonus (SPM) that showed no response to the administration of sumatriptan ${ }^{4}$. Gambardela et al. in 1997 reported a case after remove of intestinal lymphoma which showed no response to the use of sumatriptan $^{11}$. Many drugs were tried and the only effective was clonazepan. In these two reports the patients with SPM did not respond to the administration of sumatriptan ${ }^{4,11}$.

The treatment of PM is variable, with better results in those with PPM ${ }^{1-3,5,6,10-14}$. In all patients it should be carried a trial with sumatriptan, even those with possible secondary PM, to differentiate clinically the PPM from SPM ${ }^{4,10,15}$.

The most common reports of treatment of PM are with the use of clonazepan, anticholinergics drugs, 5-hydroxytryptophan, levodopa, baclofen, piracetan and anticonvulsant drugs ${ }^{1-3,5,6,10-15}$. There is a report of PM following Behçet's disease ameliorated by ceruletide (a potent analogue of CCK octapeptide $)^{14}$. Bogucki reported relief of PM with injections of botox in the muscles of soft palate ${ }^{13}$.

In the two cases we report the pattern of palatal myoclonus was slightly different . Case 1 with secondary PM showed a partial and not lasting response to the use of sumatriptan SC and no response to the use of different kinds of oral drugs. Case 2 with essential or primary type of PM showed an excellent and long lasting response to the use of a low dosage of clonazepan. These two cases exemplify the different response to two different drugs, probably due to different diseases or may represent a heterogeneous disorder ${ }^{15}$.

\section{REFERENCES}

1. Jankovic J, Pardo R. Segmental myoclonus: clinical and pharmacological study. Arch Neurol 1986;43;1025-1031.

2. Deuschl G, Mischke G, Schenck E, Schulte-Mönting J, Lucking CH. Symptomatic and essential rhythmic palatal myoclonus. Brain 1990;113:1645-1672.

3. Vieregge P, Klein C, Gehrking E, Körtke D, Kömpf D. The diagnosis of "essential palatal tremor". Neurology 1997;49:248-249.

4. Scott BL, Evans RW, Jankovic J. Treatment of palatal myoclonus with sumatriptan. Mov Disord 1996;11:748-751.

5. Matsuo F, Ajax ET. Palatal myoclonus and denervation supersensitivity in the central nervous system. Ann Neurol 1979;5:72-78.

6. Yokota T, Hirashima F, Ito Y, Tanabe H, Furukawa T, Tsukagoshi H. Idiopathic palatal myoclonus. Acta Neurol Scand 1990;81;239-242.

7. Dubinsky RM., Hallet M, Di Chiro G, Fulham M, Schwankhaus J. Increased glucose metabolism in the medulla of patients with palatal myoclonus. Neurology 1991;41:557-562.

8. Wilms H, Sievers J, Deuschl G. Lesioning of the GABAergic cerebello-olivary projection in the rat. Mov Disord1998;13:358.

9. Nishigaya K, Kaneko M, Nagaseki Y, Nukui H. Palatal myoclonus induced by extirpation of a cerebellar astrocytoma: case report. J Neurosurg 1998;88:1107-1110.

10. Martinez-Vila E, Martinez-Lage P, Luquin MR, Martínez-Lage JM. Palatal myoclonus and opioid peptides. Acta Neurol Scand 1993;88;227-228.

11. Gambardella A, Zappia A, Valentino P, et al.. Action palatal tremor in a patient with primary intestinal lymphoma. Mov Disord 1997;12:794-797.

12. Bhatt M, Snow B, Varelas M, Calne D. Palatal myoclonus : treatment with 5-hydroxytryptophan and carbidopa. Mov Disord 1990;5:339-340.

13. Bogucki A. Botulinun toxin injections under electromyography guidance. Neurol Neurochir Pol 1998;32:85-93.

14. Iwasaki Y, Kinoshita M, Ikeda K, Shiojima T. Palatal myoclonus following Behçet's disease ameliorated by ceruletide, a potent analogue of CCK octapeptide. J Neurol Sci 1991;105:12-13.

15. Pakian A, Lang A . Essential palatal tremor: evidence of heterogeneity based on clinical features and response to sumatriptan. Mov Disord 1999;14:179-180. 